\title{
Application of alkaline phosphatase for heavy metals precipitation using ascorbic acid 2-phosphate as an effective natural substrate
}

\author{
G. Chaudhuri · P. Venu-Babu - D. Dalal \\ W. R. Thilagaraj
}

Received: 2 April 2014/Revised: 5 November 2014/Accepted: 30 December 2014/Published online: 14 January 2015

(C) Islamic Azad University (IAU) 2015

\begin{abstract}
The utility of alkaline phosphatase in the precipitation of heavy metals such as $\mathrm{Ni}^{2+}, \mathrm{Cd}^{2+}, \mathrm{Cr}^{3+/ 6+}$, and $\mathrm{Co}^{2+}$ (from single-ion solutions as well as tannery and electroplating industrial effluents) under alkaline $\mathrm{pH}$ was studied with respect to bacterial alkaline phosphatase (enzyme from Escherichia coli C90) and calf intestinal alkaline phosphatase using ascorbic acid 2-phosphate, a natural substrate. Kinetic characteristics of both the enzymes at different regimes of $\mathrm{pH} 8-11$ were studied to find the potential of the enzymes to remain active at certain environmental conditions. Maximum enzymatic activity was recorded at $\mathrm{pH} 9.5$ and 10 for bacterial alkaline phosphatase and calf intestinal alkaline phosphatase, respectively. The precipitation of metal ions from singleion solutions by bacterial alkaline phosphatase and calf intestinal alkaline phosphatase occurred in the order: $\mathrm{Cd}^{2+}>\mathrm{Ni}^{2+}>\mathrm{Co}^{2+}>\mathrm{Cr}^{3+}>\mathrm{Cr}^{6+}$ and $\mathrm{Co}^{2+}>\mathrm{Cd}^{2+}$ $>\mathrm{Ni}^{2+}>\mathrm{Cr}^{6+}>\mathrm{Cr}^{3+}$, respectively. The percentage of precipitation of $\mathrm{Cr}^{6+}$ from tannery effluent (initial concentration $560 \mathrm{ppm}$ ) by bacterial alkaline phosphatase was found to be $15.57 \%$ at $300 \mathrm{~min}$ while it was $71.47 \%$ by calf intestinal alkaline phosphatase within $120 \mathrm{~min}$. Bacterial alkaline phosphatase was found to be more efficient than calf intestinal alkaline phosphatase in removing $\mathrm{Cd}^{2+}$ from electroplating effluents from an initial concentration of $734 \mathrm{ppm}$, and the percentage of precipitation by the enzymes was 94.6 and $66 \%$, respectively. This work
\end{abstract}

G. Chaudhuri · D. Dalal · W. R. Thilagaraj ( $\square)$

Department of Biotechnology, School of Bioengineering, SRM

University, Kattankulathur 603203, Tamil Nadu, India

e-mail: thilagaraj.richard@gmail.com

P. Venu-Babu

Nuclear Agriculture and Biotechnology Division, Bhabha

Atomic Research Centre, Trombay, Mumbai 400085, India demonstrates a promising eco-friendly approach for a sustainable environment, as ascorbic acid 2-phosphate is a naturally occurring and biodegradable substrate.

Keywords Bioprecipitation · Eco-friendly · Green chemistry $\cdot$ Industrial effluents $\cdot$ Single-ion solutions

\section{Introduction}

Heavy metals such as cadmium, nickel, cobalt, lead, chromium, and zinc are used in metallurgy, mining, tannery, electronic, and electroplating industries. These heavy metals being highly toxic, carcinogenic, and mutagenic can lead to serious health problems in living organisms, when the levels exceed threshold values in the effluents. They also tend to accumulate in the bodies of living organisms causing risk to health and even the survival of organisms on prolonged exposure. Efficient and selective bioremediation methods for the removal of heavy metals from the effluents are gaining importance because of many inherent limitations with traditional methods. Present-day researches are more focused on "Green Chemistry" that is ecofriendly and cost-effective (Alcalde et al. 2006). One of the leading methods in the "Green Chemistry" area is the use of biocatalysts involving enzymes or whole microorganisms. The disadvantage of using microorganisms is the difficulty in maintaining optimum conditions for their growth and survival, e.g., oxygen availability, moisture levels, pollutant levels, $\mathrm{pH}$, and temperature (Baker and Herson 1994). On the contrary, the use of enzymes also known as "White Biotechnology" (Alcalde et al. 2006) is more desirable for enhanced bioremediation because of the inherent capacity of the enzymes to remain active under a wide range of environmental conditions (Ahuja et al. 2004; 
Gianfreda and Rao 2004). Moreover, enzymatic precipitation produces less toxic or biodegradable end products (Ruggaber and Talley 2006).

One such potential class of enzymes is alkaline phosphatase (E.C.3.1.3.1) (AP), which is widely distributed in nature, ranging from prokaryotes to eukaryotes (Hoylaerts et al. 1997). APs are homodimeric metalloenzymes containing two $\mathrm{Zn}$ and one $\mathrm{Mg}$ atoms on each catalytic site (Millan 2006). By nature, APs are hydrolytic enzymes that catalyze the hydrolysis of esters of phosphoric acid. In addition, the enzymes can also carry out transphosphorylation in the presence of large concentrations of phosphate acceptors (Millan 2006) and can react with a broad range of substrates (synthetic as well as natural). The aim of the present study was to show that inorganic phosphate-mediated precipitation of metals $\left(\mathrm{Cr}^{3+/ 6+}, \mathrm{Cd}^{2+}, \mathrm{Ni}^{2+}\right.$, and $\mathrm{Co}^{2+}$ ) can occur as bacterial alkaline phosphatase (BAP) or calf intestinal alkaline phosphatase (CIAP) react with a natural substrate, i.e., ascorbic acid 2-phosphate. The kinetic behavior of the enzymes, viz. BAP and CIAP, in the presence of para-nitrophenyl phosphate ( $p$ NPP), a synthetic substrate, and their applicability for the precipitation of heavy metals were the focus of our earlier studies (Chaudhuri et al. 2013a, b, c).

The advantage of using ascorbic acid 2-phosphate as a substrate is that the end product, i.e., ascorbic acid (vitamin $\mathrm{C}$ ), is completely environment-friendly. The precipitation mechanism is as follows:

ascorbic acid 2-phosphate + BAP/CIAP

$\rightarrow$ ascorbic acid + phosphate

metal $^{n+}+$ phosphate $\rightarrow$ metal - phosphate (precipitation)

\section{Materials and methods}

\section{Materials}

BAP from Escherichia coli $\mathrm{C} 90$ and mammalian alkaline phosphatase from calf's intestine, i.e., CIAP, were obtained from invitrogen and stored at $-20^{\circ} \mathrm{C}$. L-ascorbic acid 2-phosphate sesquimagnesium salt hydrate (Sigma Chemicals Co.) was used as substrate throughout the experiments. $50 \mathrm{mM}$ Tris- $\mathrm{HCl}$ was used as buffer, and the $\mathrm{pH}$ was maintained in the range of $8-11$ during the course of experiments. $\mathrm{Cd}^{2+}, \mathrm{Ni}^{2+}, \mathrm{Co}^{2+}, \mathrm{Cr}^{3+}$, and $\mathrm{Cr}^{6+}$ single-ion metal solutions were prepared from $\mathrm{CdCl}_{2}, \mathrm{NiCl}_{2}, \mathrm{CoCl}_{2}$, $\mathrm{K}_{2} \mathrm{CrO}_{4}$, and $\mathrm{K}_{2} \mathrm{Cr}_{2} \mathrm{O}_{7}$, respectively, and two concentrations of the metal ion solutions (250 and 1,000 ppm) were used throughout the experiments. All solutions were prepared by dissolving the salts in concentrated $\mathrm{HCl} / \mathrm{HNO}_{3}$ and adding deionized water to make up the volume. All the chemicals used were of analytical grade.
Analysis of tannery and electroplating effluents

Effluents discharged from tannery and electroplating industries were obtained from different industries situated in Chennai, Tamil Nadu, India, and stored at $4{ }^{\circ} \mathrm{C}$ till use. The $\mathrm{pH}$ of the tannery and electroplating effluents was found to be 9 and 10, respectively. Acid digestion of the effluents was performed using a mixture of nitric acid and perchloric acid (5:1) as described before (Chaudhuri et al. 2013b), and the quantification of the metals was done using atomic absorption spectrophotometer (AAS).

Study of kinetic behavior of both APs with ascorbic acid 2-phosphate as substrate

In order to understand the effect of $\mathrm{pH}$ and substrate concentration on the activity of BAP and CIAP, detailed kinetic studies were conducted and the enzyme activity was determined spectrophotometrically (Shimadzu UV-160 spectrophotometer) at $265 \mathrm{~nm}$ by measuring the amount of ascorbic acid released (Hewitt and Dickes 1961). The effect of varying substrate concentration $(1,3,5,7,9,11$, $13,15$, and $17 \mathrm{mM})$ and $\mathrm{pH}(\mathrm{pH} 8,8.5,9,9.5,10,10.5$, and 11 ) on the activity of both BAP and CIAP was recorded. The reactions were conducted in a volume of $3 \mathrm{~mL}$ at $37{ }^{\circ} \mathrm{C}$ for $60 \mathrm{~min}$, and the reaction mixture consisted of Tris- $\mathrm{HCl}$, enzyme, and substrate. The reactions were stopped by adding $1.0 \mathrm{~mL}$ of $1 \mathrm{M} \mathrm{K}_{2} \mathrm{HPO}_{4}-\mathrm{KOH}$ buffer, $\mathrm{pH}$ 10.4. All the reactions were performed in triplicate to minimize the experimental error.

Enzyme-mediated precipitation studies

Typical reactions containing $50 \mathrm{mM}$ Tris- $\mathrm{HCl}$ buffer, $50 \mathrm{mM}$ ascorbic acid 2-phosphate, 250/1,000 ppm singleion solutions $\left(\mathrm{Ni}^{2+} / \mathrm{Cd}^{2+} / \mathrm{Co}^{2+} / \mathrm{Cr}^{6+} / \mathrm{Cr}^{3+}\right)$ or electroplating or tannery effluent, and $10 \mathrm{U}$ of enzyme (BAP/CIAP) in a volume of $2 \mathrm{~mL}$ were incubated at $37^{\circ} \mathrm{C}$ for appropriate incubation periods. For BAP, the incubation period was 60,120 , and $300 \mathrm{~min}$, whereas for CIAP the incubation period was 30, 60, and $120 \mathrm{~min}$. Along with the samples, appropriate controls were also maintained. At the end of the specific incubation period, the reaction was stopped by adding $10 \mathrm{M} \mathrm{NaOH}$ followed by centrifugation $(15,000 \times g)$ for $15 \mathrm{~min}$. The amount of heavy metal precipitated was derived by analyzing the amount of heavy metal remaining in the supernatant, and the percentage of metal precipitated was determined using the formula:

$x=(a-b) / a \times 100$

where $x$ is the $\%$ of metal precipitation, $a$ is the initial concentration of metal in the aliquot, and $b$ is the final 
concentration of metal in the aliquot (i.e, in the supernatant).

Statistical analysis

SPSS 17.0 software (SPSS Inc., Chicago, IL, USA) was used to carry out the statistical analysis. Data were summarized as mean \pm standard error of the mean (SEM). The difference in the mean between the two groups, i.e., two $\mathrm{pH}$ regimes (either $\mathrm{pH} 9.5$ and $\mathrm{pH} 10.5$ or $\mathrm{pH} 8$ and 10) and two concentrations (250 and 1,000 ppm) was tested using " $t$ " test at 0.05 level with $95 \%$ confidence interval.

\section{Results and discussion}

The efficiency of an enzyme to precipitate metal ions from industrial wastewater is the manifestation of how actively the enzyme shows its performance. In order to understand the efficiency of BAP (E. coli C90) and CIAP under varying assay conditions, kinetic studies of the enzymes were performed with the natural substrate ascorbic acid 2-phosphate.

Kinetic behavior of APs with ascorbic acid 2-phosphate as substrate

$\mathrm{pH}$ is an important factor that influences the activity of alkaline phosphatase. Not only do different alkaline phosphatases have different $\mathrm{pH}$ optima for their activity, they may also vary from substrate to substrate. Since the potential of BAP and CIAP along with ascorbic acid 2-phosphate as substrate is being reported as a new heavymetal remediating tool, the effect of $\mathrm{pH}$ and substrate concentration on BAP and CIAP activity was investigated under varying $\mathrm{pH}(8-11)$ and substrate concentrations (1-17 mM). Both the enzymes responded favorably with the increase in the concentration of the substrate, viz. ascorbic acid 2-phosphate, and there has been almost linear increase in the activity of the alkaline phosphatases up to a substrate concentration of $13 \mathrm{mM}$, regardless of the $\mathrm{pH}$ regime. The maximum enzyme activity for BAP was recorded at $\mathrm{pH} 9.5$ (Fig. 1a), whereas for CIAP it was at $\mathrm{pH}$ 10 (Fig. 1b). However, to ensure the availability of excess amount of $\mathrm{P}_{\mathrm{i}}$ during precipitation reactions, $50 \mathrm{mM}$ ascorbic acid 2-phosphate was used during experiments with single-ion solutions and effluents from industries.

\section{Bioprecipitation of metal ions from single-ion solutions}

The preferable $\mathrm{pH}$ range to work with industrial waste streams is $8-11$, since the $\mathrm{pH}$ of the effluents lies within this range. The amount of ascorbic acid liberated is directly
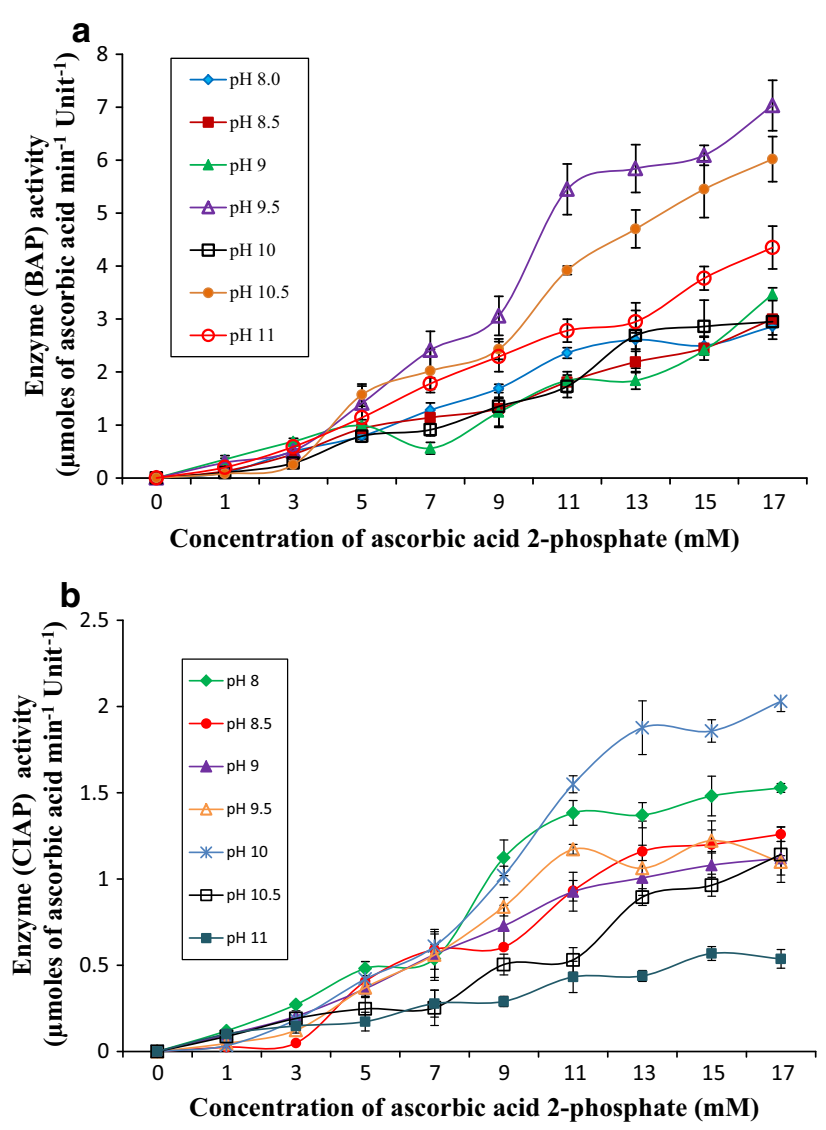

Fig. 1 Hydrolysis of ascorbic acid 2-phosphate by BAP (a) and CIAP (b) under different concentrations of substrate and varying $\mathrm{pH}$ regimes. Reaction conditions: incubation period $=60 \mathrm{~min}$, temperature $=37{ }^{\circ} \mathrm{C}$, buffer $=50 \mathrm{mM}$ Tris $-\mathrm{HCl}($ Mean $\pm \mathrm{SD} ; n=3)$

proportional to the amount of inorganic phosphate dissociated from the substrate. In order to determine the effect of $\mathrm{pH}$ on metal precipitation, studies were carried out at $\mathrm{pH}$ 9.5 and 10.5 with BAP and at $\mathrm{pH} 8$ and 10 with CIAP, as the enzymes registered good catalytic activity at these $\mathrm{pH}$ regimes (Fig. 1a, b).

$\mathrm{Cd}^{2+}$ precipitation from single-ion solutions by BAP and CIAP

Cadmium is a highly toxic and carcinogenic heavy metal, which is usually present in the wastewater of industries associated with mining, electroplating, electronic, and metallurgical activities (Nagata et al. 2008; Bai et al. 2008). According to Central Pollution Control Board (CPCB), India, the permissible limit of cadmium in industrial effluent is $2 \mathrm{ppm}$ (CPCB 1986). Pagnanelli et al. have shown that cadmium can be bioprecipitated or biosorped by sulfate-reducing bacteria (SRB), but at a growth permissible $\mathrm{pH}$ of 7, 7.5, and 8. Further, the maximum concentration of SRB and their activity was reported only 
during the first 5 days indicating it to be a slow process. The approach suffers from the fact that in the presence of cadmium, sulfate reduction rate gets reduced (Pagnanelli et al. 2010).

Bioaccumulation of cadmium by a cadmium-resistant Pseudomonas aeruginosa strain KUCd1 was also reported by Sinha and Mukherjee (2009) at $\mathrm{pH} 8.5$, under strict aerobic conditions as well as continuous supply of nutrients. On the other hand, precipitation of cadmium as cadmium sulfide via hydrogen sulfide generation under completely anaerobic conditions in Pseudomonas aeruginosa, Salmonella typhimurium, and Treponema denticola has been reported by several authors (Wang et al. 1997, 2000, 2001; White and Gadd 1996; Bang et al. 2000). Application of such technology on a large scale is quite impractical. To circumvent the problem, Bai et al. tried to remove cadmium by using Rhodobacter sphaeroides, a phototrophic bacterium that is omnipresent in soil, wastewater, activated sludge, fresh, and marine water. However, the precipitation was found to be biomass-dependent and longer period of incubation, i.e., $54 \mathrm{~h}$, as opposed to $42 \mathrm{~h}$ resulted in lesser recovery of $\mathrm{Cd}$ (in other words, only $14 \%$ instead of $97 \%$ recovery) from $40 \mathrm{ppm}$ cadmium sulfate solution (Bai et al. 2008). To develop a potential bioremediation technique, BAP and CIAP along with ascorbic acid 2-phosphate were used in this study to remove cadmium from industrial wastewater. The experiments were set up with two different concentrations (250 and 1,000 ppm) of cadmium single-ion solution. The maximum precipitation of $\mathrm{Cd}^{2+}$ by BAP and CIAP was achieved at $\mathrm{pH} 9.5$ and $\mathrm{pH} \mathrm{10,} \mathrm{respectively} \mathrm{(Fig.} \mathrm{2a,} \mathrm{b).}$

In the case of BAP, for the single-ion concentration of $250 \mathrm{ppm}$ and $\mathrm{pH} 9.5$, the precipitation reached $87.36 \%$ at 60 min with a steady and small increase there after registering $>90 \%$ precipitation at $300 \mathrm{~min}$ of incubation. As the concentration of cadmium was increased to $1,000 \mathrm{ppm}$, there was 10-15\% reduction in the precipitation compared to what was achieved with $250 \mathrm{ppm}$. For the treatment of $1,000 \mathrm{ppm}$ at $\mathrm{pH} 9.5$, BAP gave precipitation of 79.67, 88.33 , and $93.29 \%$ in 60,120 , and $300 \mathrm{~min}$, respectively.

Like BAP, CIAP also showed a similar pattern of precipitation of cadmium. CIAP gave significantly better precipitation for a single-ion concentration of $250 \mathrm{ppm}$ than 1,000 ppm $(p<0.05)$. From Fig. $2 b$, it can be clearly interpreted that at 30-min incubation period, the precipitation was significantly less compared to the precipitation at 60 and 120 min irrespective of metal concentration and $\mathrm{pH}$ employed. A rapid increase in the precipitation was noticed from 30- to 60-min incubation period, whereas during 60-120 min, a steady slow increase was noticed. Maximum precipitation of cadmium catalyzed by CIAP could be achieved with an incubation period of $60 \mathrm{~min}$ and
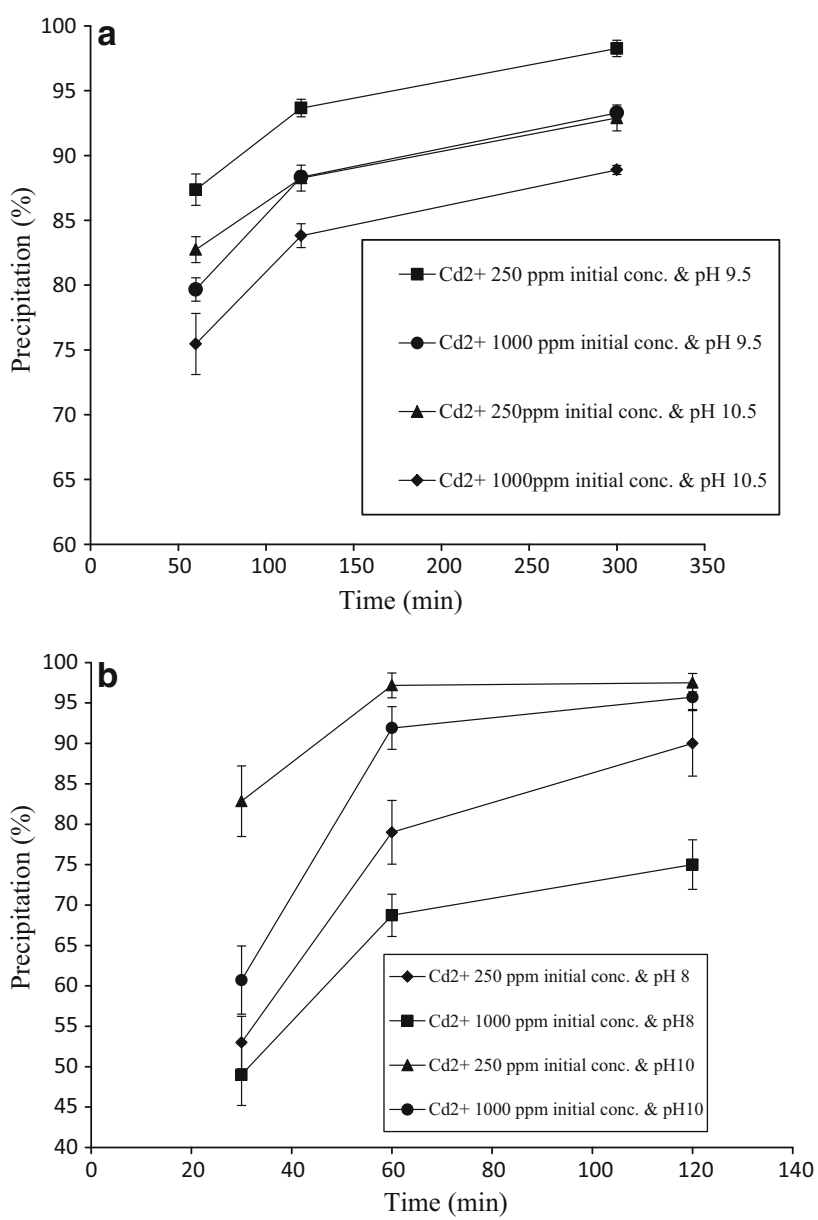

Fig. 2 Percentage of precipitation of $\mathrm{Cd}^{2+}$ by BAP (E. Coli C90) (a) and CIAP (b) with ascorbic acid 2-phosphate as substrate from different concentrations of the single-ion solution at different $\mathrm{pH}$ (Mean $\pm \mathrm{SEM} ; n=3$ )

$250 \mathrm{ppm}$ initial concentration of cadmium at $\mathrm{pH} 10$ (Fig. 2b).

The enzymes displayed quite opposing characteristics with respect to $\mathrm{pH}$ of the reaction; while BAP registered better $\mathrm{Cd}^{2+}$ precipitation at $\mathrm{pH} 9.5$ compared to $\mathrm{pH} 10.5$ $(p<0.05)$, it was $\mathrm{pH} 10$ that favored greater precipitation with CIAP compared to $\mathrm{pH} 8(p<0.05)$.

$\mathrm{Cr}^{6+}$ and $\mathrm{Cr}^{3+}$ precipitation from single-ion solutions by BAP and CIAP

Several industrial operations such as electroplating, leather, wood preservation are responsible for the discharge of high amount chromium into the environment. Hexavalent chromium is more toxic and hazardous than the trivalent chromium. But the trivalent chromium can also be harmful, if present beyond the maximum permissible contaminant level (Hidayah and Mangkoedihardjo 2010). The 
maximum allowable limit for total chromium in inland surface water in India is $2 \mathrm{ppm}$ (CPCB 1986). World Health Organization has formulated the permissible limit of total $\mathrm{Cr}$ in drinking water as 0.05 ppm (WHO 2008). Hidayah and Mangkoedihardjo (2010) have shown that rice husk can act as biostimulator for the growth of xenobiotic degrading bacteria, viz. Pseudomonas fluorescens, which helps in the removal of $\mathrm{Cr}^{6+}$ from the polluted soil. Apart from being slow, this process needs additional external sources, e.g., carbon, nitrogen, and phosphorous. Memon et al. (2009) have reported that banana peel could be a good sorbent for $\mathrm{Cr}^{6+}$ but the optimal sorption was found to be at $\mathrm{pH} 2$, and it was also seen that during the adsorption process, considerable amount of $\mathrm{Cr}^{6+}$ got reduced to $\mathrm{Cr}^{3+}$. Further adsorption studies with banana peel revealed that optimum $\mathrm{Cr}^{3+}$ occurred at $\mathrm{pH} 4$, and the presence of other cations and anions would interfere with the process (Memon et al. 2008).

On the contrary, in the present investigation, it has been found that both BAP and CIAP along with $\mathrm{L}$-ascorbic acid 2-phosphate are capable of reducing the concentration of $\mathrm{Cr}^{6+}$ and $\mathrm{Cr}^{3+}$ from single-ion solutions by precipitating them as $\mathrm{Cr}\left(\mathrm{PO}_{4}\right)_{2}$ and $\mathrm{CrPO}_{4}$, respectively. Significantly, more precipitation was found to occur $(p<0.05)$ when the initial concentration of the single ion was low (250 ppm).

BAP and CIAP displayed different patterns of precipitation of chromium. BAP registered more or less a linear increase in the precipitation of $\mathrm{Cr}^{6+}$ and $\mathrm{Cr}^{3+}$ regardless of $\mathrm{pH}$ and initial concentration of chromium in the reactions (Fig. 3a, b). The maximum amount of $\mathrm{Cr}^{6+}$ and $\mathrm{Cr}^{3+}$ could be precipitated at $300 \mathrm{~min}$ after incubation. Higher $\mathrm{pH}$ (10.5) and higher initial concentration of chromium $(1,000 \mathrm{ppm})$ were found to be inhibitory. BAP yielded precipitation of $32.94 \%$ of $\mathrm{Cr}^{6+}$ and $54.96 \%$ of $\mathrm{Cr}^{3+}$ during $300 \mathrm{~min}$ of incubation with $250 \mathrm{ppm}$ initial concentration at $\mathrm{pH}$ 9.5. On the other hand, CIAP catalyzed quite significant precipitation of $\mathrm{Cr}^{6+}$ and $\mathrm{Cr}^{3+}$ amounting to 96.88 and $81.61 \%$ for an initial concentration of $250 \mathrm{ppm}$ chromium at $\mathrm{pH} 10$ within 60 min of incubation (Fig. 4a, b). The striking difference in the CIAP- and BAP-driven precipitation of chromium was that while increasing $\mathrm{pH}(8-10)$ promoted the precipitation of the metal in the former, it was (pH 9.5-10.5) inhibitory for the latter. Further, in the case of CIAP, the levels of precipitation of $\mathrm{Cr}^{6+}$ and $\mathrm{Cr}^{3+}$ under both $\mathrm{pH}$ regimes and initial concentrations attained more or less highest values within 60 min of incubation followed by a steady and small increase thereafter.

$\mathrm{Ni}^{2+}$ precipitation from single-ion solutions by BAP and CIAP

Wastewater from electroplating industries as well as aircraft and motor vehicle manufacturing industries contain
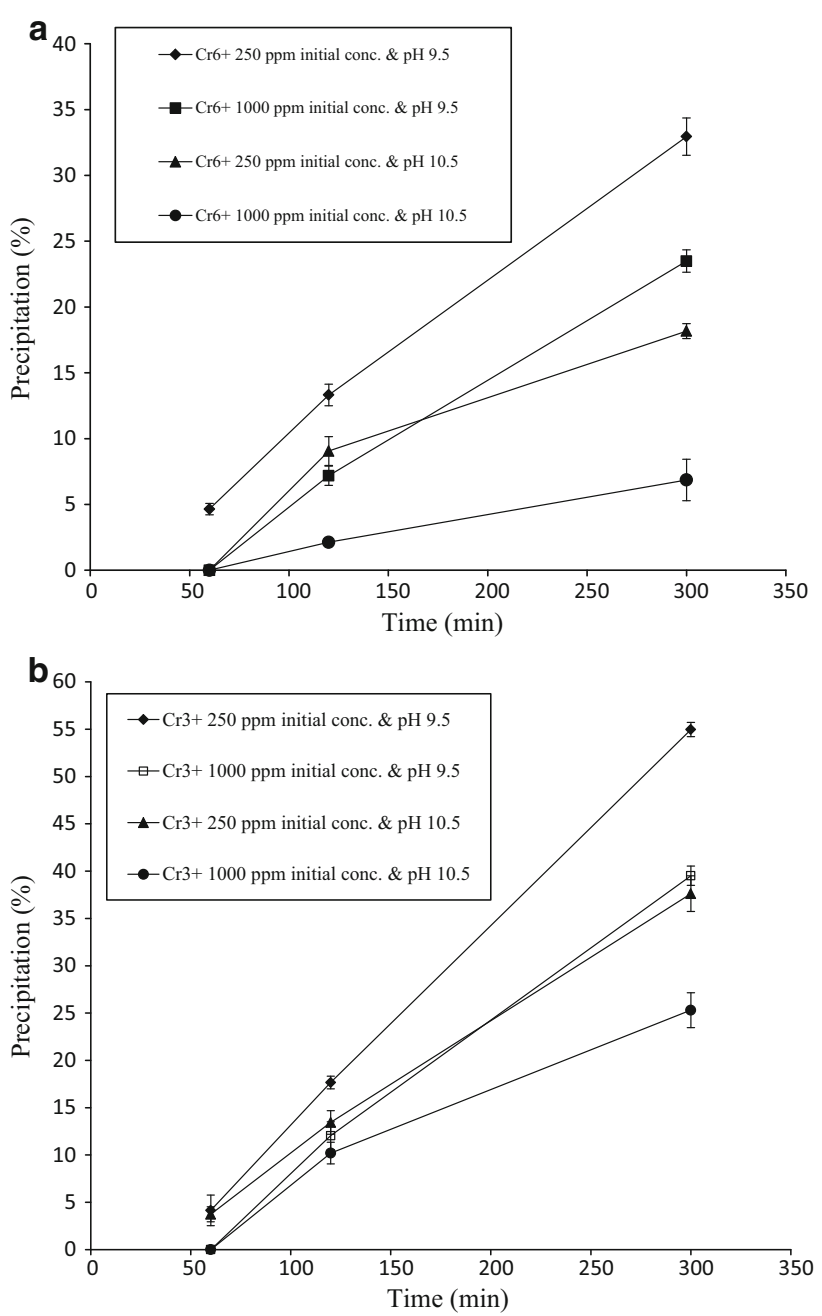

Fig. 3 Percentage of precipitation of $\mathrm{Cr}^{6+}$ (a) and $\mathrm{Cr}^{3+}$ (b) by BAP (E. coli $\mathrm{C} 90)$ with ascorbic acid 2-phosphate as substrate, from different concentrations of the single-ion solutions at different $\mathrm{pH}$ (Mean \pm SEM; $n=3$ )

huge amount of nickel (Edwin 2008). Though according to WHO the amount of nickel in drinking water should not exceed more than $0.1 \mathrm{ppm}$, most of the electroplating effluent contains nickel more than the acceptable limit (Edwin 2008). The permissible limit of nickel set by CPCB in industrial effluent is 3 ppm (CPCB 1986). Among all the heavy metals present in the industrial effluents, nickel is the most difficult ion to be remediated either by physicochemical techniques or by bioremediation (Basnakova and Macaskie 2001). Compared to other metals, nickel has been reported to be less responsive to biosorption process (Irving and Williams 1953). Removal of nickel at acidic $\mathrm{pH}$ ranging from $\mathrm{pH} 4$ to 6 by weakly basic chelating anion exchange resins was reported by Dave et al. (2011). Nickel accumulation by genetically modified microorganisms (GMO) was reported, but for the treatment of wastewater, application of engineered strains of microorganisms has 

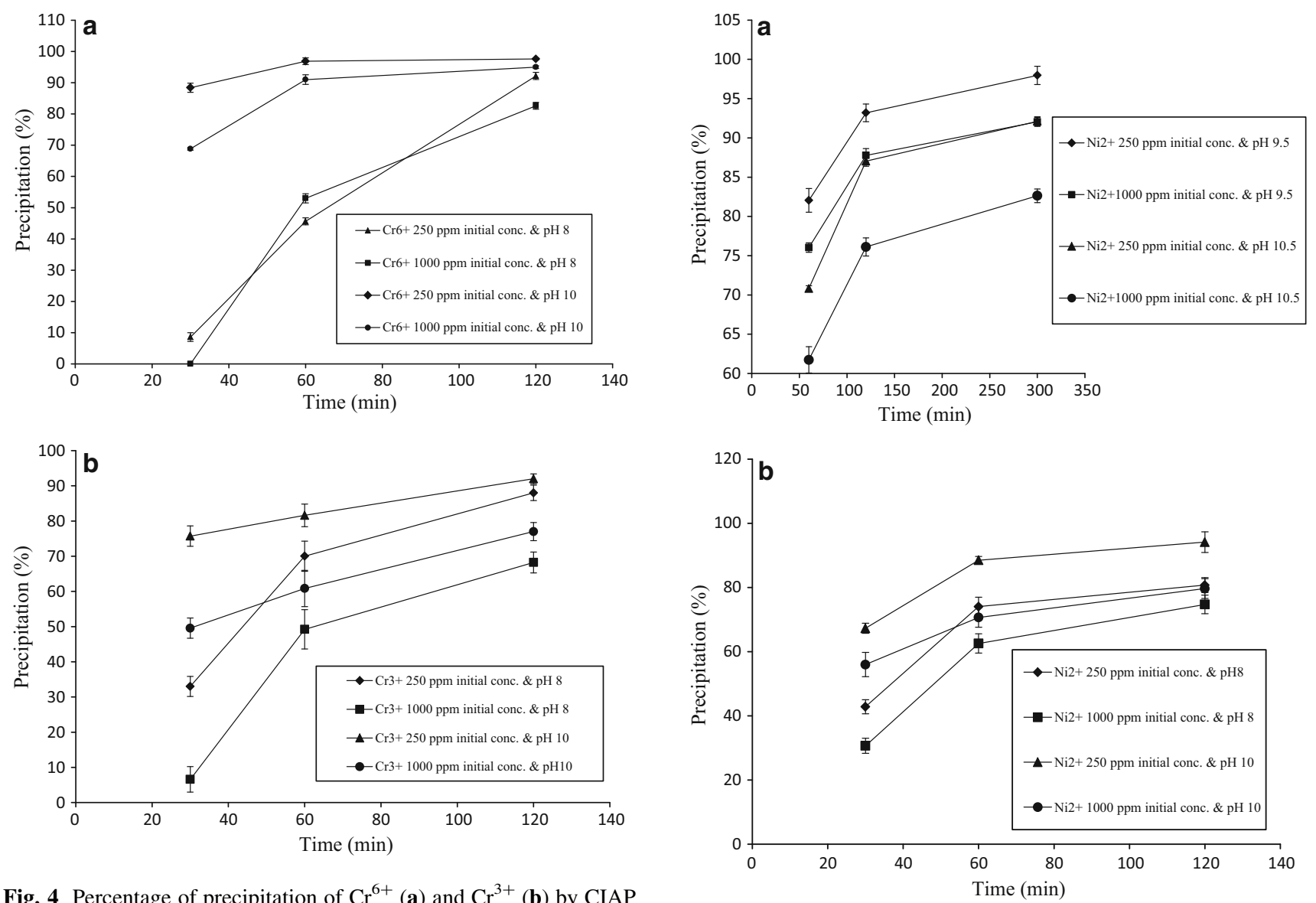

Fig. 4 Percentage of precipitation of $\mathrm{Cr}^{6+}$ (a) and $\mathrm{Cr}^{3+}$ (b) by CIAP with ascorbic acid 2-phosphate as substrate, from different concentrations of the single-ion solutions at different $\mathrm{pH}$ (Mean $\pm \mathrm{SEM}$; $n=3$ )

not been possible so far (Krishnaswamy and Wilson 2000). Nickel can also be precipitated as nickel sulfide, but sulfide itself has harmful effects on living organisms (Pumpel et al. 2003). The current investigation reveals that enzymatic bioprecipitation of $\mathrm{Ni}^{2+}$ is affected by several operating parameters such as $\mathrm{pH}$, metal concentration, incubation period, and the type of enzyme being used. The results obtained in this study with BAP and CIAP with ascorbic acid 2-phosphate as substrate allowed us to infer that BAP yields more precipitation of $\mathrm{Ni}^{2+}$ as nickel phosphate $\left[\mathrm{Ni}_{3}\left(\mathrm{PO}_{4}\right)_{2}\right]$ than CIAP for the same metal concentration used. Between the two different concentrations (250 and 1,000 ppm) employed in the experiments, $250 \mathrm{ppm} \mathrm{Ni}^{2+}$ was almost completely precipitated (97.96\%) as nickel phosphate by BAP at $\mathrm{pH} 9.5$ during the incubation period of $300 \mathrm{~min}$, whereas at higher concentration, i.e., $1,000 \mathrm{ppm}$, the precipitation was somewhat lesser $(92.04 \%)$ (Fig. 5a). On the other hand, the results obtained with CIAP-mediated precipitation (Fig. 5b) showed that $250 \mathrm{ppm}$ of initial $\mathrm{Ni}^{2+}$ concentration gave more precipitation $(94.13 \%)$ than $1,000 \mathrm{ppm}(79.66 \%)$ at

Fig. 5 Percentage of precipitation of $\mathrm{Ni}^{2+}$ by BAP (E. coli C90) (a) and CIAP (b) with L-ascorbic acid 2-phosphate as substrate, from different concentrations of the single-ion solution at different $\mathrm{pH}$ $($ Mean \pm SEM; $n=3$ )

pH 10 after an incubation for $120 \mathrm{~min}$. For both the enzymes, an initial concentration of $250 \mathrm{ppm}$ appeared to be more conducive for the precipitation to occur than $1,000 \mathrm{ppm}(p<0.05)$. The enzymes differed in their performance in terms of precipitation of $\mathrm{Ni}^{2+}$ with respect to the $\mathrm{pH}$ of the reaction. Within the regimes of $\mathrm{pH}$ tested with CIAP (pH 8 and 10) and BAP (pH 9.5 and 10), higher $\mathrm{pH}$ (10) was preferred by the former, while the latter performed better at a lower pH (9.5) (Fig. 5a, b). Further, at any given time period, $\mathrm{pH}$, and initial concentration, $\mathrm{BAP}$ performed significantly better than CIAP.

$\mathrm{Co}^{2+}$ precipitation from single-ion solutions by BAP and CIAP

Cobalt is beneficial to life only when present in minor concentrations, but could be detrimental at higher levels. Runoff from mining operations, industrial effluents, and urban storm water is the usual source of cobalt in the environment (Triantafyllou et al.1999). Environmental 
Bureau of Investigation (Canadian Water Quality Guidelines) has set the allowable limits of cobalt in the irrigation water and livestock wastewater at 0.05 and $1 \mathrm{mg} \mathrm{L}^{-1}$, respectively (Rengaraj and Moon 2002). Bhatnagar et al. 2010 carried out the sorption experiments with lemon peel at $\mathrm{pH} 6$ and an incubation period of $10 \mathrm{~h}$ at $25^{\circ} \mathrm{C}$ and observed that lemon peel (adsorbent dose $10 \mathrm{~g} \mathrm{~L}^{-1}$ ) adsorbed $22 \mathrm{mg} \mathrm{g}^{-1}$ of cobalt from an initial concentration of cobalt up to $1,000 \mathrm{ppm}$. But the phenomenon was found to be temperature-dependent leading to less adsorption at temperature higher than $25{ }^{\circ} \mathrm{C}$. Moreover, there are no reports of adsorption of cobalt by lemon peel at alkaline $\mathrm{pH}$. The extraction of cobalt from dilute sulfate solution by supported liquid medium (SLM) and solvent extraction (SX) was reported by Swain et al. (2007), but these experiments were also conducted at acidic $\mathrm{pH}$. While the precipitation of cobalt as cobalt sulfide by sulfur-reducing bacteria (SRB) was reported, it has also been felt that SRB impose certain growth conditions for their performance (Satyawali et al. 2010). In the current investigation, both the enzymes, viz. BAP and CIAP, were found to be capable of precipitating cobalt as cobalt phosphate $\left[\mathrm{Co}_{3}\left(\mathrm{PO}_{4}\right)_{2}\right]$ with ascorbic acid 2-phosphate as substrate. From Fig. 6a, it can be observed that BAP precipitated $(85.85 \%)$ significantly $(p<0.05)$ more cobalt at $\mathrm{pH} 9.5$ and $300 \mathrm{~min}$ of incubation period from an initial concentration of $250 \mathrm{ppm}$ than $1,000 \mathrm{ppm}(76.1 \%)$. Precipitation was less at $60 \mathrm{~min}$ but as the incubation time increased, there was increased hydrolysis of ascorbic acid 2-phosphate by BAP, resulting in more $P_{i}$ liberation, which precipitated cobalt as cobalt phosphate. During incubation between 120 and $300 \mathrm{~min}$, there was small but steady increase in the precipitation of cobalt. Further, it could be inferred from Fig. 6a that there was lesser precipitation brought about by BAP at $\mathrm{pH} 10.5$ than at $\mathrm{pH} 9.5(p<0.05)$.

In contrast, CIAP was found to be more effective for cobalt precipitation than BAP for the same metal concentration used. Like in the case of BAP, the metal phosphate precipitation with CIAP was also higher when the initial concentration of cobalt was increased from 250 to $1,000 \mathrm{ppm}(p<0.05)$. With $250 \mathrm{ppm}$ initial concentration, almost all cobalt was precipitated $(98.16 \%)$ at $\mathrm{pH} 10$ and 120-min incubation period (Fig. 6b). Even for 1,000 ppm initial concentration, quite high percentage of precipitation of cobalt was observed $(92.66 \%)$ under the experimental conditions (Fig. 6b). The effect of $\mathrm{pH}$ on cobalt precipitation by CIAP was also studied. Though in the case of CIAP less precipitation was observed at $\mathrm{pH} 8$ than at $\mathrm{pH} 10$ $(p<0.05)$, the difference was not too high (Fig. 6b). It was observed that for $250 \mathrm{ppm}$ initial concentration of cobalt at pH 8 and 120-min incubation period, the precipitation was $97 \%$ (almost equivalent to the precipitation found at $\mathrm{pH}$
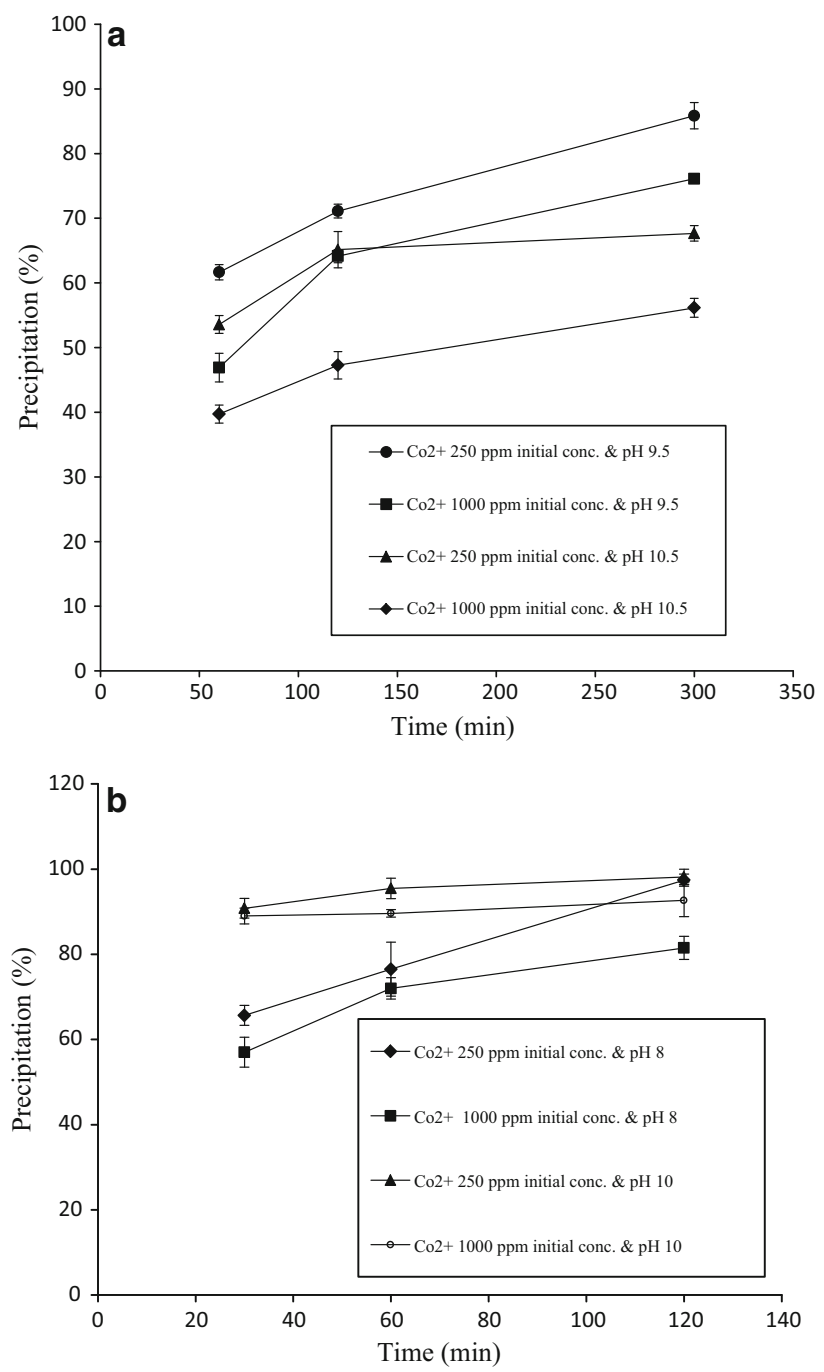

Fig. 6 Percentage of precipitation of $\mathrm{Co}^{2+}$ by BAP (E. coli C90) (a) and CIAP (b) with ascorbic acid 2-phosphate as substrate, from different concentrations of the single-ion solution at different $\mathrm{pH}$ (Mean \pm SEM; $n=3$ )

10), while in the case of $1000 \mathrm{ppm}$, at $\mathrm{pH} 8$ and 120-min incubation period, the precipitation observed was $81.5 \%$.

Therefore, it could be stated that the enzyme BAP is more affected than CIAP by cobalt as an ion than the $\mathrm{pH}$ in the precipitation reactions.

BAP- and CIAP-mediated precipitation of heavy metals from industrial effluents

The efficiency of enzymatic precipitation of heavy metals from actual industrial effluents was corroborated by treating the effluents with BAP and CIAP along with the substrate. The initial concentration of $\mathrm{Cd}^{2+}$ in electroplating effluent was estimated to be $734 \mathrm{ppm}$. After treatment with BAP for 60,120 , and $300 \mathrm{~min}$ at $\mathrm{pH} 9.5$, the percentage of 
$\mathrm{Cd}^{2+}$ precipitation was $81.94,91.39$, and $94.62 \%$ for the respective time periods (Fig. 7). Similar treatment with CIAP for 30,60 , and $120 \mathrm{~min}$ at $\mathrm{pH} 10$ showed 32.75 , 53.75 , and $65.89 \%$ precipitation of $\mathrm{Cd}^{2+}$, respectively (Fig. 8). From tannery effluent, the removal of $\mathrm{Cr}^{6+}$ (initial concentration $560 \mathrm{ppm}$ ) was also determined by treating the effluent with the enzymes (BAP and CIAP) along with ascorbic acid 2-phosphate as substrate. Compared to CIAP, the BAP showed very less precipitation. At $\mathrm{pH} 9.5$ and incubation period of 60,120 , and $300 \mathrm{~min}$, the percentage of precipitation of $\mathrm{Cr}^{6+}$ by BAP was $0,5.61$, and $15.57 \%$, respectively (Fig. 7). On the other hand, it was 38.32, 64.55, and $71.47 \%$ in CIAP-derived precipitation reactions at $\mathrm{pH} 10$ and incubation period of 30, 60, and 120 min, respectively (Fig. 8).

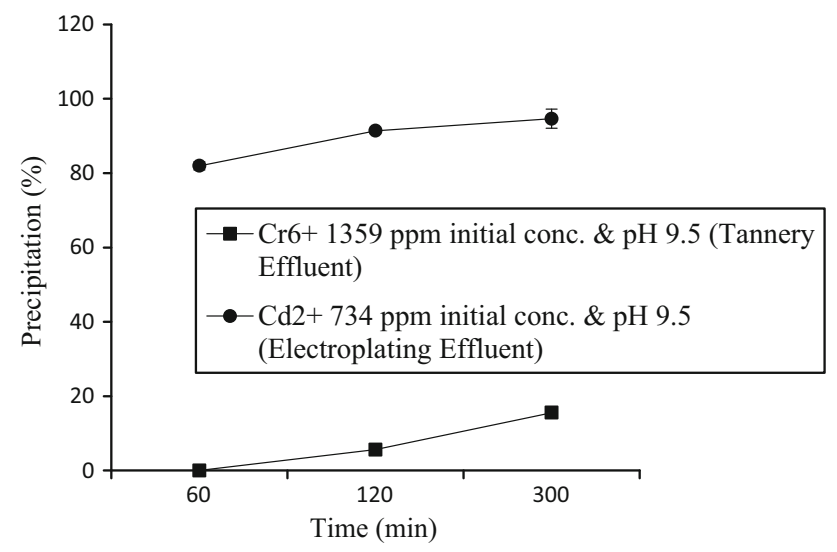

Fig. 7 Bioprecipitation of heavy metals from industrial effluents (tannery and electroplating) using BAP with ascorbic acid 2-phosphate as substrate at $\mathrm{pH} 9.5$ (Mean $\pm \mathrm{SEM} ; n=3$ )

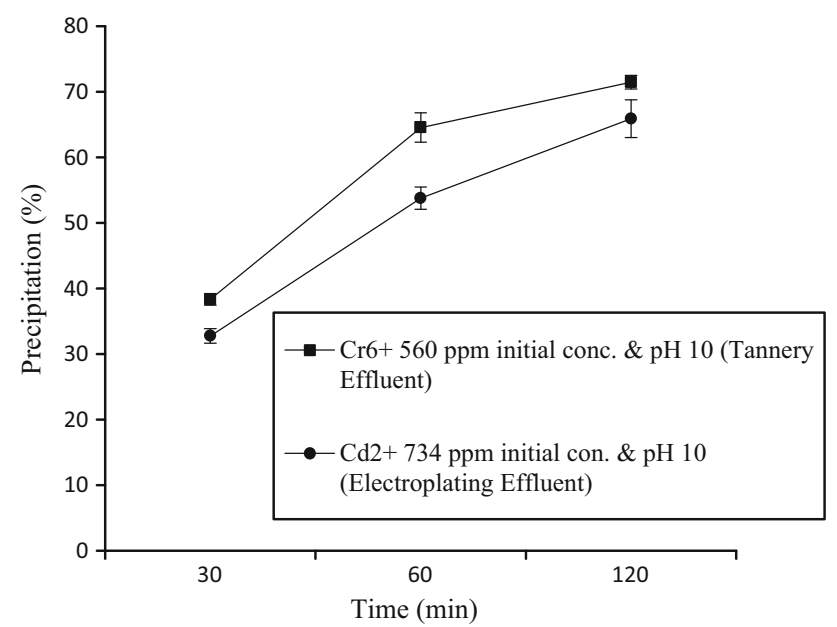

Fig. 8 Bioprecipitation of heavy metals from industrial effluents (tannery and electroplating) using CIAP with ascorbic acid 2-phosphate as substrate at $\mathrm{pH} 10$. (Mean $\pm \mathrm{SEM} ; n=3$ )
Average precipitation of metal ions by alkaline phosphatases

In order to get a better understanding of preferential precipitation by the enzymes, the precipitation values obtained in the experiments across the $\mathrm{pH}$ regimes, concentration of single-ion solutions, and incubation periods employed using BAP and CIAP were taken into account to obtain average values of precipitation for each metal. It turned out that the precipitation of heavy metals is favored by BAP in the order: $\mathrm{Cd}^{2+}>\mathrm{Ni}^{2+}>\mathrm{Co}^{2+}>\mathrm{Cr}^{3+}>\mathrm{Cr}^{6+}(93.33 \%>$ $91.18 \%>71.44 \%>39.35 \%>20.36 \%$, respectively) while CIAP-driven precipitation followed a different pattern, i.e., $\mathrm{Co}^{2+}>\mathrm{Cr}^{6+}>\mathrm{Cd}^{2+}>\mathrm{Ni}^{2+}>\mathrm{Cr}^{3+}(92.44 \%>$ $91.89 \%>89.72 \%>82.31 \%>81.35 \%$, respectively).

\section{Conclusion}

In the current study, precipitation reactions were carried out both with single-ion solutions and effluents from tannery and electroplating industries. CIAP was found to precipitate $\mathrm{Cd}, \mathrm{Ni}, \mathrm{Co}$, and $\mathrm{Cr}^{3+/ 6+}$ at a faster rate (within $120 \mathrm{~min}$ of incubation), achieving near completion or maximum precipitation, compared to $300 \mathrm{~min}$ of incubation required for BAP. Both $\mathrm{Cr}^{3+}$ and $\mathrm{Cr}^{6+}$ were found to be quite inhibitory to the activity of BAP while CIAP was largely unaffected by the ions, and the mammalian enzyme could precipitate as much as $80-90 \%$ of the toxic metal. However, BAP was also found to be equally effective in precipitating $\mathrm{Cd}, \mathrm{Ni}$, and $\mathrm{Co}$. The results also suggested that metal precipitation is strongly dependent on incubation period, metal concentration, and $\mathrm{pH}$ of the reaction. During the in vitro precipitation reactions, no scavenging of $\mathrm{P}_{\mathrm{i}}$ liberated is expected; hence, the amount of inorganic phosphate liberated for metal phosphate formation should be constant in all comparable reactions. Therefore, the differences in the levels of precipitation with different ions could be explained as a result of different kinetics of metal ion-phosphate formation as well as the radical effect of metal ions on the amino acid backbone of the enzyme, alkaline phosphate. The subunits of alkaline phosphate from E. coli and calf intestine contain four cysteine residues as two intra-chain disulfides (Coleman 1992; Sone et al. 1997) while the latter has an additional cysteine residue in free form (Millan 2006). Further, the enzymes from both the sources share only 25-30\% sequence homology (Murphy and Kantrowttz 1994), which can be attributed to the differences observed in the enzyme kinetics and the pattern of precipitation reactions with different heavy metal ions.

The results obtained in this study also demonstrate the potential of BAP and CIAP for removing heavy metals 
such as $\mathrm{Cd}$ and $\mathrm{Cr}^{6+}$ from effluents of tannery and electroplating industries. Scaled-up reactions as well as immobilized BAP/CIAP could be attempted for ascertaining the feasibility of applying the technology at field level using ascorbic acid 2-phosphate as an eco-friendly, safe, and convenient method for treating industrial effluents.

Acknowledgments The authors are grateful to SRM University (Kattankulathur, Tamil Nadu, India) for providing all facilities to carry out the research work.

\section{References}

Ahuja SK, Ferreira GM, Moreira AR (2004) Utilization of enzymes for environmental applications. Crit Rev Biotechnol 24:125-154

Alcalde M, Ferrer M, Plou FJ, Ballesteros A (2006) Environmental biocatalysis: from remediation with enzymes to novel green processes. Trends Biotechnol 24:281-287

Bai H-J, Zhang Z-M, Yang G-E, Li B-Z (2008) Bioremediation of cadmium by growing Rhodobacter sphaeroides: kinetic characteristic and mechanism studies. Bioresour Technol 99:7716-7722

Baker KH, Herson DS (1994) Microbiology and biodegradation. Bioremediation, McGraw-Hill, New York, pp 9-60

Bang W, Clark DS, Keasling JD (2000) Cadmium, lead and zinc; removal by expression of the thiosulfate reductase gene from Salmonella typhimurium in Escherichia coli. Biotechnol Lett 22:1331-1335

Basnakova G, Macaskie LE (2001) Microbially-enhanced chemisorption of $\mathrm{Ni}_{2} \mathrm{C}$ ions into biologically-synthesised hydrogen uranyl phosphate (HUP) and selective recovery of concentrated $\mathrm{Ni}_{2} \mathrm{C}$ using citrate or chloride ion. Biotechnol Lett 23:67-70

Bhatnagar A, Minochaa AK, Sillanpaa M (2010) Adsorptive removal of cobalt from aqueous solution by utilizing lemon peel as biosorbent. Biochem Eng J 48:181-186

Central Pollution Control Board, Ministry of Environment and Forests (Govt. of India) (1986) The Environment Protection Rules

Chaudhuri G, Chatterjee S, Venu-Babu P, Ramasamy K, Thilagaraj WR (2013a) Kinetic behaviour of calf intestinal alkaline phosphatase with $p$ NPP. Indian J Biochem Biophys 50:64-71

Chaudhuri G, Shah GA, Dey P, Ganesh S, Venu-Babu P, Thilagaraj WR (2013b) Enzymatically mediated bioprecipitation of heavy metals from industrial wastes and single-ion solutions by mammalian alkaline phosphatase. J Environ Sci Health A Tox Hazard Subst Environ Eng 48:79-85

Chaudhuri G, Dey P, Dalal D, Venu-Babu P, Thilagaraj WR (2013c) A novel approach to precipitation of heavy metals from industrial effluents and single-ion solutions using bacterial alkaline phosphatase. Water Air Soil Pollut 224:1-11

Coleman JE (1992) Structure and mechanism of alkaline phosphatase. Annu Rev Biophys Biomol Struct 21:441-483

Dave RS, Dave GB, Mishra VP (2011) Removal of nickel from eletroplating waste water by weakly basic chelating anion exchange resins: DOWEX 50x4, DOWEX 50x2 AND DOWEX M-4195. J Appl Sci Environ Sanit 6:39-44

Edwin Vasu A (2008) Adsorption of $\mathrm{Ni}(\mathrm{II}), \mathrm{Cu}(\mathrm{II})$ and $\mathrm{Fe}(\mathrm{III})$ from aqueous solutions using activated carbon. Electron J Chem 5:1-9

Gianfreda L, Rao MA (2004) Potential of extra cellular enzymes in remediation: a review. Enzyme Microb Technol 35:339-354

Hewitt EJ, Dickes GJ (1961) Spectrophotometric measurements on ascorbic acid and their use for the estimation of ascorbic acid and dehydroascorbic acid in plant tissues. Biochem J 78:384
Hidayah WR, Mangkoedihardjo S (2010) Rice husk for bioremediation of chromium (VI) polluted soil. Int J Acad Res 2:35-38

Hoylaerts MF, Manes T, Millan JL (1997) Mammalian alkaline phosphatases are allosteric enzymes. J Biol Chem 272:22781-22787

Irving H, Williams RJP (1953) The stability of transition-metal complexes. J Chem Soc 3192-3210

Krishnaswamy R, Wilson DB (2000) Construction and characterization of an Escherichia coli strain genetically engineered for Ni(II) bioaccumulation. Appl Environ Microbiol 66:5383-5386

Memon JR, Memon SQ, Bhanger MI, Khuhawar MY (2008) Banana peel: a green and economical sorbent for $\mathrm{Cr}(\mathrm{III})$ removal. Pak J Anal Environ Chem 9:20-25

Memon JR, Memon SQ, Bhanger MI, El-Turki A, Hallam KR, Allen GC (2009) Banana peel: a green and economical sorbent for the selective removal of $\mathrm{Cr}(\mathrm{VI})$ from industrial waste water. Colloids Surf B 70:232-237

Millan JL (2006) Alkaline phosphatases structure, substrate specificity and functional relatedness to other members of a large super family of enzymes. Purinergic Signal 2:335-341

Murphy JE, Kantrowttz ER (1994) Why are mammalian alkaline phosphatases much more active than bacterial alkaline phosphatases? Mol Microbiol 12:351-357

Nagata T, Kimura T, Pan-Hou H (2008) Engineering expression of polyphosphate confers cadmium resistance in tobacco. J Toxicol Sci 33:371-773

Pagnanelli F, Viggi CC, Toro L (2010) Isolation and quantification of cadmium removal mechanisms in batch reactors inoculated by sulphate reducing bacteria: biosorption versus bioprecipitation. Bioresour Technol 101:2981-2987

Pumpel T, Macaskie LE, Finlay JA, Diels L, Tsezos M (2003) Nickel removal from nickel plating waste water using a biologically active moving-bed sand filter. Biometals 16:567-581

Rengaraj S, Moon S-H (2002) Kinetics of adsorption of Co (II) removal from water and waste water by ion exchange resins. Water Res 36:1783-1793

Ruggaber TP, Talley JW (2006) Enhancing bioremediation with enzymatic processes: a review. Pract Period Hazard Toxic Radioact Waste Manag 10:73-85

Satyawali Y, Schols E, Roy SV, Dejonghe W, Diels L, Vanbroekhoven K (2010) Stability investigations of zinc and cobalt precipitates immobilized by in situ bioprecipitation (ISBP) process. J Hazard Mater 181:217-225

Sinha S, Mukherjee SK (2009) Pseudomonas aeruginosa KUCD1, a possible candidate for cadmium bioremediation. Braz J Microbiol 40:655-662

Sone M, Kishigami S, Yoshihisa T, Ito K (1997) Roles of disulfide bonds in bacterial alkaline phosphatase. J Biol Chem 272:6174-6178

Swain B, Jeong J, Lee J-C, Lee G-H (2007) Extraction of Co (II) by supported liquid membrane and solvent extraction using Cyanex 272 as an extractant: a comparison study. J Memb Sci 288:139-148

Triantafyllou S, Christodoulou E, Eou-Syngouna P (1999) Removal of nickel and cobalt from aqueous solutions by Na-activated bentonite. Clays Clay Miner 47:567-572

Wang CL, Michels PC, Dawson SC, Kitisakkul S, Baross JA, Keasling JD, Clark DS (1997) Cadmium removal by a new strain of Pseudomonas aeruginosa in aerobic culture. Appl Environ Microbiol 63:4075-4078

Wang CL, Maratukulam PD, Lum AM, Clark DS, Keasling JD (2000) Metabolic engineering of an aerobic sulfate reduction pathway and its application to precipitation of cadmium on the cell surface. Environ Microbiol 66:4497-4502

Wang CL, Ozuna SC, Lum AM, Clark DS, Keasling JD (2001) Aerobic sulfide production and cadmium precipitation by 
Escherichia coli expressing the Treponema denticola cysteine desulfhydrase gene. Appl Microbiol Biotechnol 56:425-430

White C, Gadd GM (1996) Mixed sulphate-reducing bacterial cultures for bio-precipitation of toxic metals: factorial and response-surface analysis of the effects of dilution rate, sulphate and substrate concentration. Microbiology 142:2197-2205
World Health Organisation (2008) Guidelines for drinking-water quality, 3rd edn. Incorporating the first and second addenda, Geneva, p 334 